\title{
Pengaruh Current Ratio dan Total Asset Turnover Terhadap Return On Asset (Studi Kasus Industri Pertambangan Sub Sektor Minyak Dan Gas Bumi di Bursa Efek Indonesia Periode 2015-2019)
}

\author{
Fadil Iskandar \\ Fakultas Ekonomi Prodi Manajemen, Universitas Batanghari Jambi \\ Corresponding email : fdliskandar00@gmail.com
}

\begin{abstract}
This research aims, first to analyze how ts that affect the Current Ratio, and Total Asset TurnOver on Return on Asset of simultaneous empirical study on mining industry sub sector of oil and gas at listed in Indonesia Stock Exchange period 20152019. Secondly to analyze how that affect the Current Ratio, Total Turn Over Assets and Total Asset TurnOver on Return on Asset of partially empirical study on mining industry sub sector of oil and gas at listed in Indonesia Stock Exchange period 2015-2019. The research methodology is descriptive and quantitative analysis methods. Data used is secondary data. The population become object in this research is mining industry sub sector of oil and gas industries period 2015-2019. Amount sample the used is three industry company and still stand up during period of perception and also publicized of year of 2015-2019 by Indonesian Stock Exchange the analysis multiple regression, hypotesis test so determinant coefficient $F$ test and t test. The object of this research is mining industry sub sector of oil and gas industries listed on the Stock Exchange Indonesia 2015-2019 have seven (7) emiten is PT Ratu Prabu Energi,Tbk (ARTI), PT Astrindo Nusantara Infrastruktur, Tbk, PT Elnusa Tbk PT Energi Mega Persada Tbk, PT Surya Esa Perkasa Tbk, PT Medco Energi Internasional Tbk, PT Radiant Utama Interinsco Tbk. Research results model of regression equation is $Y=2,300-0.837 X_{1}+0.404 X_{2}+e . F$ test result, it is known that variabels Current Ratio and Total Asset Turn Over simultaneously significant effect on Return on Asset. F count larger than F table (5,722 > 3,29) or comparing the significant level of 0.05 then $(0.008<0.05)$ then Ho is rejected and Ha accepted. Based on the results of the $t$ test, Current Ratio and Total Asset Turnover variable have significant effect on Return on Asset. Conclusion is the variable Current Ratio and Total Asset Turn Over variabels simultaneously and partially significant effect on Return on Asset
\end{abstract}

Keyword : Current Ratio, Total Asset TurnOver, Return on Asset

\section{Pendahuluan}

Pada era globalisasi saat ini setiap negara dituntut untuk semakin maju dan berkembang seiring dengan zaman dimana setiap negara harus mampu mengacu pada perekonomian. Pada umumnya pendirian suatu perusahaan bertujuan untuk memaksimalkan keuntungan yang diperoleh agar kelangsungan hidup usahanya terjamin dan dapat mengembangkan usahanya. Dalam menghadapi persaingan bisnis, suatu perusahaan haruslah benar-benar memperhatikan hal yang sangat fundamental yaitu berkenaan dengan permodalan. Suatu perusahaan diharapkan harus memberikan perhatian penuh dalam masalah penggunaan dana. Hal ini dilakukan dengan tujuan meningkatkan citra perusahaan dimata konsumen dan mempertahankan pelanggan yang secara langsung mempertahankan kegiatan operasional perusahaan. Perusahaan merupakan salah satu unit kegiatan produksi yang mengelola sumber - sumber ekonomi untuk menyediakan barang atau jasa bagi konsumen dengan tujuan untuk memperoleh keuntungan dan dapat memenuhi kebutuhan konsumen.

Dorongan perusahaan untuk mencari sumber pembiayaan yang dapat menyediakan dana dengan jumlah yang cukup besar yang digunakan untuk mengembangan usaha, peningkatan produksi dan kegiatan perusahaan lainnya. Karenanya perusahaan memerlukan kinerja keuangan yang efektif dan efisien agar tujuan perusahaan dapat tercapai sesuai dengan keinginan dari perusahaan. Kinerja keuangan perusahaan merupakan satu diantara dasar penilaian mengenai kondisi keuangan perusahaan yang dilakukan berdasarkan analisa terhadap rasio keuangan. Umumnya kinerja keuangan perusahaan dikategorikan baik jika besarnya rasio keuangan perusahaan bernilai sama dengan atau di atas standar rasio keuangan. Rasio keuangan merupakan rasio yang digunakan untuk mengukur apakah permodalan yang dimilki sudah memadai atau sejauh mana penurunan yang terjadi dalam total aset yang masuk dapat ditutupi oleh capital equity. Kinerja keuangan suatu perusahaan merupakan prestasi yang dicapai perusahaan dalam suatu periode tertentu yang mencerminkan tingkat kesehatan perusahaan tersebut. Untuk melihat kinerja keuangan diperlukan laporan keuangan perusahaan sebagai alat untuk menganalisa bagi manajemen keuangan dalam mengambil keputusan yang akan datang.

Menganalisis laporan keuangan tentunya dapat menggunakan rasio-rasio keuangan. Rasio-rasio keuangan dihitung berdasarkan atas angka-angka yang ada dalam neraca saja, dalam laporan rugi laba saja, atau pada neraca dan rugi laba. Setiap analisis keuangan bisa saja merumuskan rasio tertentu yang dianggap mencerminkan aspek tertentu. Secara keseluruhan, aspek-aspek yang dinilai biasanya diklasifikasikan menjadi aspek leverage, aspek likuiditas, aspek profitabilitas atau efisiensi, dan rasio-rasio nilai pasar (Husnan, 2016). Analisis terhadap laporan keuangan 
Fadil Iskandar, Pengaruh Current Ratio dan Total Asset Turnover Terhadap Return On Asset (Studi Kasus Industri Pertambangan Sub Sektor Minyak dan Gas Bumi di Bursa Efek Indonesia Periode 2015-2019)

dengan menggunakan rasio keuangan dapat menilai kinerja keuangan perusahaan untuk mengevaluasi sehat atau tidaknya suatu perusahaan. Setiap perusahaan mempunyai asset untuk mendukung kegiatan usahanya. Asset atau yang bisa disebut aktiva ini dibagi menjadi dua yaitu aktiva lancar dan aktiva tetap. Aktiva lancar dapat diartikan menjadi aktiva yang habis dalam satu kali berputar dalam proses produksi dan proses perputarannya adalah dalam jangka waktu pendek (umumnya kurang dari satu tahun). Pentingnya tingkat aktiva lancar yang berlebih dapat dengan mudah membuat perusahaan merealisasikan pengembalian atas investasi yang rendah. Akan tetapi, perusahaan dengan jumlah aktiva lancar yang terlalu sedikit dapat mengalami kekurangan dan kesulitan dalam mempertahankan kelancaran kegiatan operasionalnya. Untuk melihat kinerja keuangan dalam kegiatan sehari-hari, aktiva lancar memiliki hubungan yang langsung dan sangat erat dengan volume penjualan. Oleh karena itu pengelolaan aktiva lancar dalam manajemen aktiva lancar merupakan cara yang paling tepat yang dapat diambil oleh perusahaan. Aktiva lancar sangat penting bagi perusahaan terutama dalam kegiatan operasionalnya. Salah satu ukuran untuk melihat potensi dari profitabilitas suatu perusahaan adalah dengan cara menganalisis Current Ratio.

Current ratio merupakan rasio yang mengukur kemampuan perusahaan untuk membayar hutang lancar dengan menggunakan aktiva lancar yang dimiliki. Semakin besar rasio ini berarti semakin likuid perusahaan. Perusahaan yang dapat mengelola rasio lancarnya dngan baik menunjukkan bahwa aktiva lancar perusahaan dapat menutup hutang lancarnya dengan kata lain, perusahaan tersebut memiliki likuiditas yang baik. Sebaliknya semakin rendah current ratio berarti perusahaan tidak memiliki cukup kas sehingga perusahaan akan sulit untuk berkembang karena jumlah kas yang sedikit serta kesulitas dalam membayar utang. Semakin besar perbandingan aktiva lancar dengan hutang lancar, maka perusahaan tersebut semakin likuid. Total Asset TurnOver merupakan bagian dari rasio aktivitas dimana rasio aktivitas digunakan untuk mengukur efektivitas perusahaan dalam menggunakan aktiva yang dimilikinya untuk menghasilkan laba. Dengan demikian hasil pengukuran dapat memperlihatkan suatu perusahaan lebih efisien dan efektif dalam mengelola aset yang dimilikinya atau mungkin justru sebaliknya. Rasio Total Asset Turn Over ini menunjukkan berapa cepat perputaran semua aktiva yang digunakan dalam siklus produksi normal, semakin cepat rasio ini, semakin baik karena dianggap bahwa kegiatan penjualan berjalan cepat. Dengan demikian perputaran tersebut akhirnya dapat meningkatkan laba yang dihasilkan oleh perusahaan.

Return On Asset merupakan salah satu bentuk dari rasio profitabilitas, Adapun manfaatnya untuk mengukur kemampuan perusahaan dalam menghasilkan laba. Dengan menggunakan total aktiva yang ada dan setelah biayabiaya modal (biaya yang digunakan mendanai aktiva) dikeluarkan dari analisis. Rasio return on asset juga mengukur efektifitas manajemen secara keseluruhan yang ditunjukkan oleh besar kecilnya tingkat keuntungan yang diperoleh dalam hubungannya dengan penjualan maupun investasi. Return on asset adalah rasio keuntungan bersih pajak, yang juga berarti suatu ukuran untuk menilai seberapa besar tingkat pengembalian dari asset yang dimiliki perusahaan. Return on asset meningkat menunjukkan bahwa dari total aktiva yang dipergunakan untuk operasi perusahaan mampu memberikan laba bagi perusahaan. Objek penelitian adalah industri pertambangan sub sektor minyak dan gas bumi yang terdaftar di Bursa Efek Indonesia selama periode 2015-2019. Di tengah fenomena pesatnya perkembangan industri pertambangan sub sektor minyak dan gas bumi saat ini menunjukkan industri ini mempunyai peluang yang sangat menjanjikan. Kebutuhan perusahaan dan masyarakat umum terus-menerus mengalami peningkatan sebagai contoh kebutuhan bahan bakar minyak untuk kendaraan ataupun bahan bakar gas.

Kebutuhan ini merupakan salah satu kebutuhan yang penting dalam masyarakat. Karena pada umumnya masyarakat saat ini melakukan aktivitas menggunakan kendaraan. Sedangkan kendaraan itu sendiri dapat bergerak memerlukan energi yang berasal dari bahan bakar minyak ataupun bahan bakar gas, dan masih banyak lagi pemakaian minyak dan gas sebagai energi pada saat ini. Populasi industri pertambangan sub sektor minyak dan gas bumi selama 2015-2019 ada 10 (sepuluh) emiten yang terdaftar pada Bursa Efek Indonesia. Sedangkan yang dapat dijadikan sampel hanya 7 (tujuh) emiten, ini dikarenakan kelengkapan data variabel untuk penelitian selama tahun pengamatan, yakni; PT Ratu Prabu Energi Tbk, PT Astrindo Nusantara Infrastruktur Tbk, PT Elnusa Tbk, PT Energi Mega Persada Tbk, PT Surya Esa Perkasa Tbk, PT Medco Energi Internasional Tbk, PT Radiant Utama Interinsco Tbk. Adapun tujuan daripada penelitian, yakni: pertama, untuk menganalisis bagaimana pengaruh current ratio, total asset turnover secara simultan terhadap return on asset pada industri pertambangan sub sektor minyak dan gas bumi selama 2015-2019. Kedua, untuk menganalisis bagaimana pengaruh current ratio, total asset turnover secara parsial terhadap return on asset pada industri pertambangan sub sektor minyak dan gas bumi selama 2015-2019.

\section{Tinjauan Pustaka dan Metode Penelitian \\ Current Ratio (CR)}

Current Ratio menurut Kasmir (2013) Rasio lancar atau (current ratio) merupakan rasio untuk mengukur kemampuan perusahaan dalam membayar kewajiban jangka pendek atau utang yang segera jatuh tempo pada saat ditagih secara keseluruhan. Dan juga Current Ratio menurut Munawir (2013) Current Ratio yaitu perbandingan antara jumlah aktiva lancar dengan hutang lancar. Ratio ini menunjukkan bahwa nilai kekayaan lancar (yang segera dapat 
dijadikan uang ) ada sekian kalinya hutang jangka pendek. Pengertian Current Ratio menurut Sutrisno (2011) Current Ratio merupakan salah satu ratio finansial yang sering digunakan. Tingkat Current Ratio dapat ditentukan dengan jalan membandingkan antara Current Asset dengan Current Liabilitie. Berdasarkan pengertian para ahli maka bahwa Current Ratio adalah rasio yang digunakan untuk mengukur kemampuan perusahaan dalam membayar hutang jangka pendek dengan cara membandingkan aset lancar dengan kewajiban lancar. Rumus yang digunakan untuk menghitung rasio ini adalah :

Current Ratio $=\frac{\text { Asset Lancar }}{\text { Kewajiban Lancar }} \times 100 \%$

\section{Total Asset Turn Over (TATO)}

Pengertian Total asset turnover menurut Kasmir (2013) Total asset turnover merupakan rasio yang digunakan untuk mengukur perputaran semua aktiva yang dimiliki perusahaan dan mengukur berapa jumlah penjualan yang diperoleh dari setiap rupiah yang dihasilkan. Dan juga pengertian Total asset turnover menurut Brigham (2011) Total asset turnover merupakan rasio yang digunakan untuk mengukur perputaran semua aktiva perusahaan, rasio ini dihitung dengan membagi penjualan dengan total aktiva. Sedangkan pengertian Total asset turnover menurut Munawir (2012) adalah : Total asset turnover menunjukkan tingkat efisiensi penggunaan seluruh aktiva perusahaan di dalam menghasilkan volume penjualan tertentu. Makin tinggi Total asset turnover berarti semakin efisien penggunaan keseluruhan aktiva di dalam menghasilkan penjualan. Berdasarkan pengertian para ahli maka dapat disimpulkan bahwa Total asset turnover adalah rasio yang digunakan untuk mengukur efisiensi penggunaan seluruh aktiva untuk meningkatkan volume penjualan dengan cara membagi penjualan dengan total aktiva. Rumus yang digunakan untuk menghitung rasio ini adalah :

Total Asset TurnOver $=\frac{\text { Penjualan }}{\text { Total Asset }} \times 100 \%$

\section{Return on Asset}

Sutrisno (2012) bahwa rentabilitas modal sendiri merupakan kemampuan perusahaan untuk menghasilkan laba dengan modal sendiri. Karena yang bekerja hanya modal sendiri, maka laba yang dibagi adalah laba untuk pemegang saham yakni earning after tax. Selanjutnya Return on Asset (ROA) adalah kemampuan perusahaan dalam menghasilkan keuntungan dengan modal sendiri yang dimiliki oleh perusahaan. Riyanto (2016) Return on Asset (ROA) adalah kemampuan dari modal sendiri untuk menghasilkan keuntungan bagi pemegang saham preferen dan saham biasa. Return on Asset (ROA) menggambarkan besarnya perolehan atas modal yang ditanamkan atau kemampuan modal sendiri untuk menghasilkan keuntungan bagi pemegang saham. Sartono (2010), menjelaskan bahwa Return on Asset (ROA), rasio yang mengukur kemampuan perusahaan memperoleh laba yang tersedia bagi pemegang saham perusahaan. Rasio ini dipengaruhi oleh besar kecilnya utang perusahaan, apabila proporsi utang makin besar maka rasio ini juga akan makin besar. Sedangkan menurut Lukman (2011) Return on Asset (ROA) merupakan suatu pengukuran dari penghasilan (Income) yang tersedia bagi para pemilik perusahaan atas modal yang mereka investasikan di dalam perusahaan. Hasil pengembalian atas ekuitas merupakan suatu ukuran dari penghasilan yang tersedia bagi para pemilik perusahaan atas modal yang diinvestasikan didalam perussahaan. Secara umum, semakin tinggi return atau penghasilan yang diperoleh, semakin baik kedudukan pemilik perusahaan. Adapun rumusnya sebagai berikut (Riyanto, 2016)

Return On Asset $=\frac{\text { Earning After Interes and Tax }}{\text { Asset }} \times 100 \%$

\section{Pengaruh Current Ratio Terhadap Return on Asset}

Current Ratio merupakan salah satu ratio finansial yang sering digunakan. Tingkat Current Ratio dapat ditentukan dengan jalan membandingkan antara Current Asset dengan Current Liabilities (Sutrisno,2011). Current Ratio menunjukkan sejauh mana aktiva lancar memenuhi kewajiban-kewajiban lancar, sehingga semakin besar perbandingan aktiva lancar dengan utang lancar semakin tinggi kemampuan perusahaan menutupi kewajiban jangka pendeknya. Rasio lancar dapat dikatakan sebagai bentuk mengukur tingkat keamanan (margin of safety). Rasio ini merupakan parameter untuk mengukur kemampuan perusahaan dalam membayar hutang jangka pendek dengan cara membandingkan aset lancar dengan kewajiban lancar. Peningkatan Current Rasio akan berdampak dengan peningkatan laba yang dihasilkan sehingga akan memberikan peningkatan return on asset yang dihasilkan (Munawir,2013). Febrioni (2017), berpendapat Pengaruh Current Ratio terhadap Return on Asset adalah semakin tinggi Current Ratio, maka Return on Asset perusahaan semakin meningkat, dan mempunyai hubungan yang positif terhadap Current Ratio. Rasio lancar yang tinggi menunjukkan adanya kelebihan aktiva lancar yang tidak baik terhadap profitabilitas perusahaan karena aktiva lancar menghasilkan return yang lebih rendah dibandingkan aktiva tetap. 


\section{Pengaruh Total Asset TurnOver Terhadap Return on Asset}

Total Asset Turnover merupakan rasio yang digunakan untuk mengukur efektifitas perusahaan dalam pemanfaatan aset untuk menghasilkan penjualan (Munawir,2012). Hasil dari Total Asset Turnover menunjukkan berapa kali perputaran aset yang dapat menghasilkan penjualan. Total Asset Turnover yang rendah dapat diartikan bahwa penjualan bersih perusahaan lebih kecil dari pada operating assets. Jika Total Asset Turnover yang tinggi menunjukkan bahwa semakin cepat perputaran aset maka akan berdampak pada laba bersih didapatkan akan meningkat. Dengan demikian perusahaan telah mampu memanfaatkan aset dalam meningkatkan penjualan yang berpengaruh terhadap perubahan laba. Peningkatan Total asset turnover menunjukkan tingkat efisiensi penggunaan seluruh aktiva perusahaan meningkat, sehingga menghasilkan volume penjualan yang optimal. Makin tinggi Total Asset TurnOver berarti semakin efisien penggunaan keseluruhan aktiva di dalam menghasilkan penjualan dan berdampak pada peningkatan laba yang dihasilkan (Brigham,2011). Secara langsung peningkatan laba yang dihasilkan akan memberikan peningkatan Return on Asset perusahaan.n Hutapea (2017), menyatakan bahwa : Semakin efektif perputaran aset perusahaan atau pengelolaan aset mampu menghasilkan kinerja perusahaan yang tinggi sehingga dapat meningkatkan laba perusahaan dan berdampak pada peningkatan Return on Asset

\section{Hipotesis}

Hipotesis daam penelitian ini adalah sebagai berikut :

H1: Ada pengaruh signifikan pengaruh current ratio, total asset turnover secara simultan terhadap return on asset pada industri pertambangan sub sektor minyak dan gas bumi selama 2015-2019

H2: Ada pengaruh signifikan pengaruh current ratio, total asset turnover secara simultan terhadap return on asset pada industri pertambangan sub sektor minyak dan gas bumi selama 2015-2019

\section{Metode}

Metode penelitian adalah suatu kegiatan untuk mencari, mencatat, merumuskan dan menganalisis sampai menyusun laporan dengan cara menggunakan pikiran secara saksama untuk mencapai suatu tujuan. Pada penelitian ini, metode yang digunakan adalah metode deskriptif kuantitatif, yakni metode yang berfungsi untuk mendeskripsikan atau memberi gambaran terhadap objek yang diteliti melalui data atau sampel yang telah ditetapkan sebagaimana adanya (Sugiyono, 2010). Dan jenis data yang digunakan dalam penelitian ini adalah data sekunder. Data sekunder merupakan data yang dikumpulkan oleh lembaga pengumpul data dan dipublikasikan kepada masyarakat pengguna data (Kuncoro, 2009). Sumber data penelitian yang tersedia di Bursa Efek Indonesia pada industri pertambangan sub sektor minyak dan gas bumi selama 2015-2019. Sumber data yang diperoleh dalam penelitian ini adalah data yang diambil berupa laporan keuangan perusahaan pada industri pertambangan sub sektor minyak dan gas bumi selama 2015-2019 melalui situs website www.idx.co.id, dan berbagai literatur yang berhubungan dengan penelitian. Sampel merupakan bagian atau wakil populasi yang memiliki karakteristik yang sama dengan populasinya (Sugiono,2010). Metode yang digunakan adalah purpusive sample yakni : sampel yang diambil berdasarkan kritria-kriteria yang ditentukan oleh peneliti sampel tersebut. Sampel pada penelitian ini ada tujuh (7) emiten yakni: PT Ratu Prabu Energi Tbk, PT Astrindo Nusantara Infrastruktur Tbk, PT Elnusa Tbk, PT Energi Mega Persada Tbk, PT Surya Esa Perkasa Tbk, PT Medco Energi Internasional Tbk, PT Radiant Utama Interinsco Tbk. Alat analisis yang digunakan untuk menguji hipotesis diajukan adalah: uji asumsi klasik, persamaan regresi linier berganda dan uji hipotesis (uji F dan uji t) yang dibantu dengan menggunakan software SPSS 22.0 (Sunjoyo dkk, 2013).

\section{Hasil \\ Uji Normalitas}

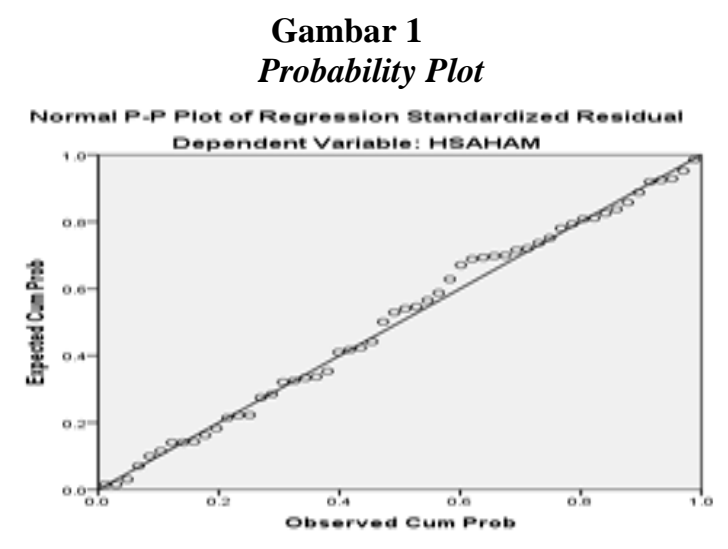

Sumber: data olahan 
Fadil Iskandar, Pengaruh Current Ratio dan Total Asset Turnover Terhadap Return On Asset (Studi Kasus Industri Pertambangan Sub Sektor Minyak dan Gas Bumi di Bursa Efek Indonesia Periode 2015-2019)

Berdasarkan Gambar 1 probability plot dapat diketahui bahwa sebaran titik-titik data residual disekitar mendekati garis diagonal, maka dapat diartikan bahwa data yang diteliti berdistribusi normal. (Sunyoto, 2013)

\section{Uji Multikolineritas}

Tabel 1

Multikolineritas

\begin{tabular}{|ll|r|r|r|}
\hline \multirow{2}{*}{ Model } & \multicolumn{2}{|c|}{ Standardized Coefficients } & \multicolumn{2}{|c|}{ Collinearity Statistics } \\
\cline { 3 - 5 } & & Beta & \multicolumn{2}{|c|}{ Tolerance } \\
\\
\cline { 3 - 5 } & (Constant) & & .834 \\
& Zscore: CR & &. .538 & .634 \\
& Zscore: TATO & .503 & .734 \\
\hline
\end{tabular}

Sumber: data olahan

Hasil perhitungan dalam penelitian ini terlihat tolerence dari ketiga variabel bebas/independen yaitu current ratio dan total asset turnover lebih besar dari 0,1 (10\%) dan Variance Inflation Factor (VIF) dari kedua (2) variabel bebas/independen lebih kecil dari 10. Maka pada model regresi berganda yang terbentuk tidak terjadi gejala multikolinearitas antara variabel bebas dalam penelitian ini. Maka disimpulkan pada penelitian ini dapat dimasukkan dalam suatu model persamaan regresi linier berganda

\section{Uji Heteroskedastisitas}

Gambar 2, terlihat titik-titik menyebar secara acak tidak membentuk pola tertentu yang jelas, serta menyebar baik di atas maupun di bawah 0 pada sumbu Y maka dapat dikatakan bahwa tidak terjadi gejala heteroskedastisitas pada model regresi linier berganda di dalam penelitian ini. Sehingga model regresi layak dapat dipakai untuk penelitian ini.

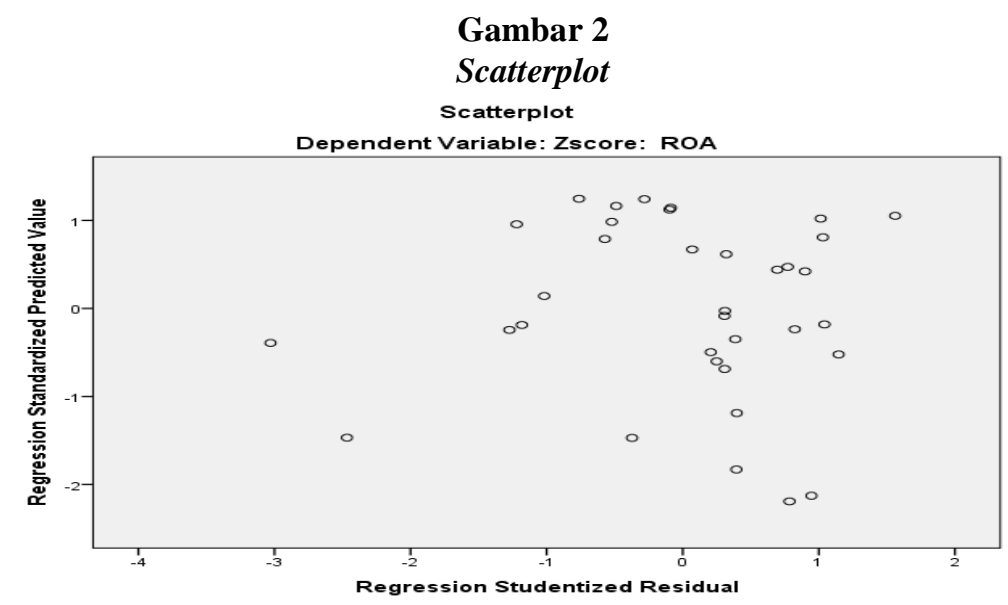

Sumber: data olahan

Uji Autokorelasi

Tabel 2

Uji Autokorelasi

\begin{tabular}{cc}
\hline Model & Durbin-Watson \\
\hline 1 & 1,434 \\
\hline
\end{tabular}

Sumber: data olahan

Tabel 2 diatas diketahui nilai Durbin-Watson sebesar 1,358. maka bahwa $-2<1,434<+2$ yang artinya adalah model regresi terbebas dari masalah autokorelasi atau tidak ada autokorelasi positif atau negatif. Maka disimpulkan bahwa penelitian ini layak dimasukkan dalam model persamaan regresi linier berganda. 
Fadil Iskandar, Pengaruh Current Ratio dan Total Asset Turnover Terhadap Return On Asset (Studi Kasus Industri Pertambangan Sub Sektor Minyak dan Gas Bumi di Bursa Efek Indonesia Periode 2015-2019)

\section{Regresi Linier Berganda}

Tabel 3

Hasil Regresi Linear Berganda

\begin{tabular}{|c|c|c|c|c|c|}
\hline \multirow{4}{*}{$\begin{array}{l}\text { Model } \\
1 \text { (Constant) } \\
\text { Zscore: CR } \\
\text { Zscore: TATO }\end{array}$} & \multicolumn{2}{|c|}{ Unstandardized Coefficients } & \multirow{2}{*}{$\frac{\text { Standardized Coefficients }}{\text { Beta }}$} & \multirow[b]{2}{*}{$\begin{array}{c}\mathrm{t} \\
3.662\end{array}$} & \multirow[b]{2}{*}{$\begin{array}{l}\text { Sig. } \\
.001\end{array}$} \\
\hline & B & $\begin{array}{l}\text { Std. Error } \\
628\end{array}$ & & & \\
\hline & -.837 & .276 & -.53 & -3.038 & .005 \\
\hline & .404 & .142 & .50 & 2.842 & .008 \\
\hline
\end{tabular}

Sumber: data olahan

Berdasarkan hasil analisis regresi berganda pada tabel 3 di atas dapat diperoleh koefisien regresi untuk variabel bebas (independen) sebagai berikut : Nilai Current Ratio sebesar -0,837, Nilai Total Asset TurnOver sebesar 0,404, Maka model persamaan regresi yang dapat dituliskan dari hasil tersebut dalam bentuk persamaan regresi linier berganda sebagai berikut : $Y=\mathbf{2 , 3 0 0}-\mathbf{0 , 8 3 7} \mathbf{X}_{\mathbf{1}}+\mathbf{0 , 4 0 4} \mathbf{X}_{2}+\mathbf{e}$

\section{Uji F}

Tabel 4

Uji statistik F

\begin{tabular}{|ll|r|r|r|r|r|}
\hline \multicolumn{1}{|c|}{ Model } & Sum of Squares & df & Mean Square & F & Sig. \\
\hline 1 & Regression & 4.443 & 2 & 2.222 & 5.722 & \\
& Residual & 12.423 & 32 & .388 & \\
Total & 16.866 & 34 & & \\
\end{tabular}

Sumber: data olahan

Hasil perhitungan menggunakan program SPSS 22, maka pertama membandingkan $F_{\text {hitung }}$ terhadap $F_{\text {tabel }}$ dengan taraf signifikan $\alpha=0,05$ (5\%). Dari tabel 4 diketahui $\mathrm{F}_{\text {hitung }}$ sebesar 5,722 dengan membandingkan $\mathrm{F}_{\text {tabel }}$ dengan $\alpha=0,05$ dan derajat bebas pembilang 2 dan derajat bebas penyebut 32, didapat $\mathrm{F}_{\text {tabel }}$ sebesar 3,29. $\mathrm{F}_{\text {hitung }}$ lebih besar dari $F_{\text {tabel }}(5,722>3,29)$. Bila dihubungkan dengan hipotesis terdahulu dapat memaknakan, Ho ditolak dan Ha diterima. Sedangkan untuk mendapatkan signifikan antar variabel independen dengan dependen, yakni dengan membandingkan sig dengan $\alpha$, sig $(0,008)<\alpha(0,05)$. Artinya variasi dari variabel independen signifikan dengan variabel dependen. Dengan demikian dikatakan bahwa variabel (Current Ratio, Total Asset Turn Over secara bersama-sama (simultan) mempunyai pengaruh signifikan terhadap Return on Asset

\section{Uji t}

Tabel 5

Uji Statistik t

\begin{tabular}{|c|c|c|c|c|c|}
\hline \multirow[b]{2}{*}{ Model } & \multicolumn{2}{|c|}{ Unstandardized Coefficients } & Standardized Coefficients & \multirow[b]{2}{*}{$\mathrm{t}$} & \multirow[b]{2}{*}{ Sig. } \\
\hline & B & Std. Error & Beta & & \\
\hline $1 \quad$ (Constant) & 2.300 & .628 & & 3.662 & .001 \\
\hline $\mathrm{CR}$ & -.837 & .276 & -.538 & -3.038 & .005 \\
\hline TATO & .404 & .142 & .503 & 2.842 & .008 \\
\hline
\end{tabular}

Sumber: data olahan

Berdasarkan tabel 5 di atas diperoleh angka $t_{\text {hitung }}$ Current Ratio (CR), sebesar -3,038, Total Asset Turn Over (TATO) sebesar 2,842. Pengujian statistik $t$ dilakukan dengan membandingkan nilai $t_{\text {hitung }}$ dengan $t_{\text {tabel. }}$ Dari pengujian maka dapat dijelaskan sebagai berikut :

1. Pengujian Variabel Current Ratio

Dari hasil perhitungan uji secara parsial diperoleh nilai thitung Current Ratio sebesar -3,038 dan nilai probabilitas signifikansi 0,005. Dari data tersebut dapat diartikan Current Ratio secara parsial berpengaruh signifikan terhadap Return on Asset karena nilai $t_{\text {hitung }}>\mathrm{t}_{\text {tabel }}(3,308>2,037)$. Sedangkan pro sig $<\alpha(0,005<0,05$. Artinya Ho ditolak dan $\mathrm{H}_{1}$ diterima.

2. Pengujian Variabel Total Asset TurnOver

Dari hasil perhitungan uji secara parsial diperoleh nilai thitung Total Asset TurnOver sebesar 2,842 dan nilai probabilitas signifikansi 0,008. Dari data tersebut dapat diartikan Current Ratio secara parsial berpengaruh 
Fadil Iskandar, Pengaruh Current Ratio dan Total Asset Turnover Terhadap Return On Asset (Studi Kasus Industri Pertambangan Sub Sektor Minyak dan Gas Bumi di Bursa Efek Indonesia Periode 2015-2019)

signifikan terhadap Return on Asset karena nilai thitung $>t_{\text {tabel }}(2.842>2,037)$. Sedangkan pro sig $<\alpha(0,008<0,05$. Artinya Ho ditolak dan $\mathrm{H}_{2}$ diterima.

\section{Koefisien Determinasi $\left(R^{2}\right)$}

Tabel 6

Koefisien Determinasi $\left(\mathbf{R}^{2}\right)$

\begin{tabular}{|c|c|c|c|c|}
\hline Model & $\mathrm{R}$ & R Square & Adjusted R Square & Std. Error of the Estimate \\
\hline 1 & $.513^{\mathrm{a}}$ & .263 & 217 & $\begin{array}{l}.62307 \\
\end{array}$ \\
\hline
\end{tabular}

Berdasarkan hasil analisis pengaruh variabel independen (Current Ratio (CR), Total Asset Turn Over (TATO), terhadap variabel dependen (Return on Asset). Dari tabel 4.6 dapat dilihat Nilai R yaitu sebesar 0,513 atau $51,3 \%$ yang berarti menunjukkan bahwa adanya hubungan cukup erat (korelasi) diantara variabel dependen dan independen sebesar 51,3\%. Dari tabel 6 juga dapat dilihat nilai koefisien determinasi (R Square) sebesar 0,263 atau 26,3\% variasi Return on Asset yang bisa dijelaskan oleh variasi dari kedua variabel independen yaitu Current Ratio (CR), Total Asset Turn Over (TATO). Sedangkan sisanya 73,7\% (100\% - 26,3\%) dijelaskan oleh faktor lain diluar penelitian.

\section{Pengaruh Current Ratio dan Total Asset Turn Over Secara Simultan Terhadap Return on Asset}

Hasil penelitian pada uji secara simultan dimana variabel independen (Current Ratio (CR), Total Asset Turn Over (TATO) secara bersama-sama (simultan) mempunyai hubungan pengaruh terhadap variabel dependen (Return on Asset) pada industri pertambangan sub sektor minyak dan gas bumi selama 2015-2019. Hal ini dapat dilihat dari hasil penelitian pada tabel 4, dimanaF $F_{\text {hitung }}$ sebesar 5,722 lebih besar dari $F_{\text {tabel }}$ yaitu $F_{\text {tabel }}$ sebesar 3,29 atau $F_{\text {hitung }}>$ $\mathrm{F}_{\text {tabel }}(5,722>3,29)$ dan nilai signifikansi yang lebih kecil dari $\alpha(0,05)$ yaitu $; 0,008<0,05$. Maka dapat dikatakan bahwa variabel independen (Current Ratio (CR), Total Asset Turn Over (TATO) secara bersama-sama (simultan) mempunyai hubungan pengaruh signifikan terhadap variabel dependen (Return on Asset). Sedangkan dari hasil penelitian pada tabel 6 didapat nilai $\mathrm{R}$ square $\left(\mathrm{R}^{2}\right)$ adalah sebesar 0,263 atau 26,3\%. Ini menunjukkan bahwa variabel independen yakni ; Current Ratio (CR), Total Asset Turn Over (TATO), mampu menjelaskan keterpengaruhannya terhadap variabel dependen (Return on Asset) hanya sebesar 26,3\%, sisanya sebesar 73,7\% dijelaskan oleh faktor lain diluar penelitian.

\section{Pengaruh Current Ratio dan Total Asset TurnOver Secara Parsial Terhadap Return on Asset}

Hasil penelitian pada tabel 5 dimana dari variabel Current Ratio (CR), Total Asset Turn Over (TATO), diperoleh angka thitung Current Ratio (CR) sebesar -3,038, Total Asset Turn Over (TATO) sebesar 2,842. Pada pengujian statistik uji $t$ dilakukan dengan membandingkan nilai $t_{\text {hitung }}$ dengan $t_{\text {tabel }}$, dimana $t_{\text {tabel }}$ didapat sebesar 2,037 . Maka pada uji $\mathrm{t}$, $\mathrm{t}_{\mathrm{hit}}$ variabel Current Ratio dibandingkan dengan $\mathrm{t}_{\mathrm{tab}}$ didapat $\mathrm{t}_{\text {hit }}$ lebih besar dari $\mathrm{t}_{\text {tab }}(2,842>2,037)$. Disisi lain untuk melihat signifikasinya dimana nilai sig Current Ratio lebih kecil dari $\alpha(0,05)$. Maka dapat disimpulkan bahwa Current Ratio berpengaruh signifikan terhadap Return on Asset pada industri pertambangan sub sektor minyak dan gas bumi selama 2015-2019. Dengan kata lain Ho ditolak dan H1 diterima. Dilain pihak dari hasil penelitian didapat $t_{h i t}$ Total Asset TurnOver sebesar 2,842. Maka bila dibandingkan dengan $t_{\text {tab }}$ maka $t_{\text {hit }}$ lebih besar dari $t_{\text {tab. }}$. Bila dilihat dari tingkat sig, maka sig lebih kecil dari $\alpha(0,05)$ atau $0,008<\alpha(0,05)$.

\section{Simpulan}

Maka dapat ditarik kesimpulan sebagai berikut :

1. Bahwa secara simultan, variabel independen yakni, Current Ratio dan Total Asset TurnOver mempunyai pengaruh signifikan terhadap Return on Asset pada industri pertambangan sub sektor minyak dan gas bumi selama 20152019 Hal ini dapat dilihat pada sub bab pembahasan perhitungan uji $\mathrm{F}$ bahwa $\mathrm{F}_{\text {hitung }}$ lebih besar dari $\mathrm{F}_{\text {tabel }}$ dan nilai signifikansi yang lebih kecil dari $\alpha(5 \%)$.

2. Secara parsial variabel independen yakni, Current Ratio, Total Asset TurnOver berpengaruh signifikan terhadap Return on Asset pada industri pertambangan sub sektor minyak dan gas bumi selama 2015-2019. Hal ini dapat dilihat dengan perhitungan Uji $\mathrm{t}$ bahwa $\mathrm{t}_{\text {hitung }}$ Current Ratio, Total Asset TurnOver lebih besar dari tabel dan nilai signifikansi yang lebih kecil dari $\alpha$ 
Fadil Iskandar, Pengaruh Current Ratio dan Total Asset Turnover Terhadap Return On Asset (Studi Kasus Industri Pertambangan Sub Sektor Minyak dan Gas Bumi di Bursa Efek Indonesia Periode 2015-2019)

\section{Daftar Pustaka}

Algifari, 2011, Statistika untuk Bisnis, Edisi Kelima, Salemba Empat, Jakarta.

Fahmi, Irham, 2012, Manajemen Keuangan, Edisi Keenam, Gramedia, Jakarta.

Hanafi, Mamduh M. dan Abdul Halim, 2009, Analisis Laporan Keuangan, Edisi Keempat, Cetakan Pertama., Yogyakarta, UPP STIM YKPN.

Harjito, dan Martono, Agus, 2010. Manajemen Keuangan. Yogyakarta: Ekonisia.

Harmono, Pram, 2009, Dasar-Dasar Pembelanjaan, Edisi Keenam, BPPE, Yogyakarta

Harahap, Sofyan, 2012, Manajemen Keuangan, Cetakan Ketiga, Erlangga, Jakarta.

Husnan, Suad, 2004, Lembaga Keuangan dan Pasar Modal, Edisi Kedua, BPPE UGM, Yogyakarta

Istijanto, Yogi, 2009, Metodologi Penelitian, Cetakan Kelima, Tigaraksa, Jakarta.

Fahmi, Irham 2012, Pengantar Manajemen Keuangan, Alfabet, Bandung.

Munawir, Sawir, 2015, Manajemen Keuangan dan Aplikasi, Edisi Kedua, Ganesha, Bandung

Mulyadi, 2014, Pengantar Manajemen Keuangan, Edisi Kelima, Ghalia, Jakarta

Kasmir, 2010, Pengantar Manajemen Keuangan, Cetakan Ke-2. Jakarta: Kencana.

Kuncoro, Mudrajad. 2013, Metode Riset untuk Bisnis dan Ekonomi, Yogyakarta: Erlangga.

Putong, Iskandar, 2013, Pengantar Ekonomi Mikro dan Makro, Ghalia, Jakarta

Riyanto, Bambang, 2016, Pengantar Manajemen Keuangan, Edisi Kelima, BPPE UGM, Yogyakarta.

Sugiyono, 2012, Dasar Pembelanjaan, Edisi Keempat, Erlangga, Yogyakarta. 2010, Metode Penelitian untuk Bisnis dan Keuangan, BPPE UGM, Yogyakarta

Sunyoto, 2013, Metode Penelitian dan Aplikasi, Edisi Keenam, Erlangga, Jakarta.

Suliyanto, 2015, Metode Riset Bisnis, Edisi Khusus, Andi Offset, Jakarta.

Sukirno, Sudono, 2013, Pengantar Ekonomi Makro, Edisi Kelima, Galilea, Jakarta

Tandelilin, Eduardus, 2012, Teori Portopolio dan Aplikasi, Edisi Kelima, Salemba Empat, Jakarta.

Widoatmojo, 2008, Pasar Modal di Indonesia, Edisi Kedua: Tiga Raksa Jakarta

Vibby, Santo, 2017, Zero Preneur, W \&G Wealth \& Grown, India. 